\title{
Examination for platelet-activating factor production by preimplantation mouse embryos using a specific radioimmunoassay*
}

\author{
M. A. Smal†, M. Dziadek $\ddagger$, S. J. Cooney $\uparrow$, M. Attard $\ddagger$ and B. A. Baldo $\dagger \S$ \\ $\dagger$ Kolling Institute of Medical Research, Royal North Shore Hospital, St. Leonards, NSW 2065 . \\ Australia; $\ddagger$ Centre for Early Human Development, Monash Medical Centre, 246 Clayton Road, \\ Clayton, Victoria 3168, Australia; and \$Department of Medicine, University of Sydney, NSW 2006, \\ Australia
}

\begin{abstract}
Summary. A specific and highly sensitive radioimmunoassay was used to measure platelet-activating factor (PAF) production by preimplantation mouse embryos in vitro. Levels of PAF greater than 1 pg per embryo were not observed in 24-h culture medium from 2-cell embryos, compacted morulae or blastocysts, or in extracts from these embryos. Synthetic PAF added to embryos at the start of culture could be almost totally recovered after the incubation period, indicating negligible degradation of PAF during culture. PAF was also not detected in embryo samples using a washed rabbitplatelet aggregation assay. It can be concluded that mouse embryos do not produce substantial levels of PAF, or any of the biologically active analogues of PAF detected by the assay.
\end{abstract}

Keyw'ords: platelet-activating factor; mouse embryos; radioimmunoassay

\section{Introduction}

Platelet-activating factor (PAF), a phospholipid with the structure 1-0-alkyl-2-0-acetyl-sn-glycero3-phosphocholine (Hanahan et al., 1980), is a potent mediator of inflammation. A role for PAF in mediating uterine vascular permeability changes at sites of embryo implantation has been proposed, and is supported by a number of studies. Both human and mouse preimplantation embryos have been shown to secrete a substance with PAF-like activity which appears to be homologous to synthetic PAF (Collier et al., 1988; Ryan et al., 1989). The level of production by human embryos appears to correlate with their potential for implantation and establishment of pregnancy (O'Neill et al., 1987). It has also been demonstrated that direct injection of PAF into the uteri of pseudopregnant rats induces a decidua-like response which is similar to that observed after embryo implantation (Acker et al., 1989). The implantation of mouse and rat embryos is inhibited by specific PAF antagonists (Spinks \& O'Neill, 1988; Acker et al., 1988), and in the mouse this inhibition is due to a direct or indirect effect of the antagonists on the embryo (Spinks et al., 1990). In addition, O'Neill et al. (1989) have shown that supplementation of human embryo culture medium with PAF results in increased pregnancy rates, possibly by stimulation of embryo metabolism. Taken together, all these data suggest that PAF has positive autocrine effects on the early preimplantation mammalian embryo, as well as being an early embryonic signal which mediates the uterine decidual reaction at implantation. However, other workers have been unable to demonstrate PAF activity by rabbit blastocysts (Angle et al., 1988b), or inhibition of an implantation response in mice with PAF antagonists (Milligan \& Finn, 1990). A role for embryo-derived

*Reprint requests to: Dr B. A. Baldo. 
PAF in early pregnancy therefore remains controversial. It still remains to be determined whether embryos produce PAF, or molecules which have some of the biological properties of PAF but which are distinct structural entities and have different responses in the various assay systems.

The detection and measurement of PAF has traditionally been based on various bioassays involving the action of PAF on platelets which either measure the extent of platelet aggregation, or the release of $\left[{ }^{3} \mathrm{H}\right]$ serotonin (Hanahan \& Weintraub, 1985). PAF production by human embryos has been assayed using the splenectomized mouse platelet bioassay (O'Neill et al., 1987). However, all these biological assays have problems of large variability within and between assays, and the need for careful control of non-specific interferences which cause platelet activation. The development of a specific radioimmunoassay (RIA) for PAF (Smal et al., 1990b) overcomes some of these problems, and allows accurate quantitation of low levels of PAF in biological samples. In the present study we have applied this RIA in an attempt to detect PAF production by preimplantation mouse embryos.

\section{Materials and Methods}

Animals. The 4-5-week-old female $\mathrm{F}_{1}$ mice (C57BL/6J $\times \mathrm{CBA} / \mathrm{H}$ ) were superovulated with 5 i.u. pregnant mares' serum gonadotrophin (PMSG; Folligon, Intervet, Sydney, Australia) followed $48 \mathrm{~h}$ later with 5 i.u. human chorionic gonadotrophin (hCG; A.P.L., Ayerst, Parramatta, NSW, Australia). The females were caged overnight with F, males of proven fertility, and examined for copulation plugs the following morning (Day 1 of pregnancy).

Embryo culture. Two-cell embryos were flushed from the oviducts of mice on Day 2 of pregnancy, into M2 medium (Quinn et al., 1982). Compacted morulae were obtained after $24-30 \mathrm{~h}$ of culture in drops of M 16 medium (Whittingham, 1971) under light-weight paraffin oil (BDH Chemicals, Kilsyth, Victoria, Australia) pre-equilibrated at $37 \mathrm{C}$ in $5 \% \mathrm{CO}_{2}$ in air. To obtain blastocyst stages, embryos were left in culture for an additional $24 \mathrm{~h}$. For analysis of PAF production, 2-cell, compacted morulae, and blastocysts were cultured in fresh M16 medium in $12 \times 75$ mm polystyrene round-bottom tubes (Labco, Braeside, Victoria, Australia), without paraffin oil. Between 25 and 45 embryos were cultured in $250 \mu \mathrm{l}$ of M 16 medium for $24 \mathrm{~h}$. Control tubes contained no embryos. In some experiments known concentrations of $\mathrm{C}_{18}-\mathrm{PAF}$ (see below) were added to the culture tubes at the start of the 24-h incubation time. After the culture period, tubes were centrifuged at $1250 \mathrm{~g}$ and the supernatant was transferred to Eppendorf tubes containing $25 \mu \mathrm{l} \mathrm{N}-\mathrm{HCl}$. Acidified samples were immediately frozen and kept at $-80^{\circ} \mathrm{C}$ until assayed. Embryo pellets were frozen directly without acidification.

Extraction of samples. Frozen samples were thawed, sonicated and $240 \mu \mathrm{l}$ were added to $900 \mu \mathrm{chloroform} /$ methanol $(1: 2 \mathrm{v} / \mathrm{v})$. Embryos alone were suspended in $240 \mu 10 \cdot 1 \%$ BSA/PBS before proceeding with extraction. The extraction mixture was vortexed and sonicated extensively before chloroform $(300 \mu \mathrm{l})$ and water $(300 \mu \mathrm{l})$ were added to effect phase separation. The upper phase was discarded and the lower chloroform phase was evaporated. The residue was then dissolved in ethanol, this was separated into samples and each sample was evaporated.

Quantitation by RIA. Each sample was reconstituted, with sonication, in $5 \mu$ l ethanol and $210 \mu l$ assay buffer. The PAF standard solution $\left(0.1 \mathrm{mg} / \mathrm{ml}\right.$ in aqueous ethanol, consisting of equal parts $\mathrm{C}_{16}-\mathrm{PAF}$ and $\left.\mathrm{C}_{18}-\mathrm{PAF}\right)$ was diluted in assay buffer to give standard solutions in the range 0.1 to $25 \mathrm{ng} / \mathrm{ml}$. Sera were acid-treated (Smal et al., 1989) to inactivate the enzyme PAF-acetylhydrolase, which hydrolyses PAF to lyso-PAF, and is known to be present in serum (Farr et al., 1980). Acid-treated anti-PAF antiserum was diluted to 1 in 8000 in assay buffer containing acid-treated normal sheep serum ( 1 in 2000). Donkey anti-sheep immunoglobulin (the second antibody) was diluted 1 in 250 in assay buffer containing $6 \%$ polyethylene glycol and $\left[{ }^{125} \mathrm{I}\right] \mathrm{PAF}$ was added to give approximately $40000 \mathrm{c}$.p.m. per $100 \mu$ l. Into duplicate polystyrene RIA tubes (Disposable Products, Technology Park, SA, Australia) was placed $100 \mu \mathrm{l}$ of each of the following: sample or PAF standard solution, anti-PAF antiserum, and anti-sheep/tracer. The $\mathbf{B}_{0}$ tubes contained no PAF, while the non-specific binding (NSB) tubes contained only anti-sheep/tracer. The tubes were incubated for $16 \mathrm{~h}$ at room temperature, and $4 \mathrm{ml}$ assay buffer were added. The tubes were centrifuged at $1900 \mathrm{~g}$ for $25 \mathrm{~min}$ and the supernatants decanted. The remaining radioactivity was counted and the percentage tracer bound to the precipitate $\left(\% \mathrm{~B} / \mathrm{B}_{0}\right)$ was calculated from the formula $(\mathrm{B}-\mathrm{NSB}) /\left(\mathrm{B}_{0}-\mathrm{NSB}\right) \times 100$. The amount of PAF was determined from the standard curve obtained by plotting PAF concentration against $\% \mathrm{~B} / \mathrm{B}_{0}$.

Platelet aggregation studies. Extracted embryo samples were reconstitued in ethanol $(2 \times$ concentrated compared to original sample) and the mixed PAF standard solution was diluted in ethanol or $0.25 \%$ BSA/PBS. Rabbit platelets were isolated and washed as described previously (Pinckard et al., 1979) and to $500 \mu \mathrm{l} \mathrm{stirred} \mathrm{(900} \mathrm{rev./min)} \mathrm{platelets,}$ suspended in Tyrode's-gelatin buffer $\mathrm{pH} 7.2$ containing $1.3 \mathrm{mM}-\mathrm{CaCl}_{2}, 5 \mu \mathrm{l}$ of test sample or PAF standard were added. Changes in optical transmission were monitored by a Payton aggregometer (Buffalo, NY, USA). To determine any PAF-inhibitory activity, platelets were treated with $5 \mu$ sample and, 1-2 min later, were stimulated with $50 \mathrm{pg}$ PAF in BSA/PBS, while monitoring the optical transmission. 
Materials. The 1-0-hexadecyl PAF ( $\left.\mathrm{C}_{16}-\mathrm{PAF}\right)$ and 1-0-octadecyl PAF $\left(\mathrm{C}_{18}-\mathrm{PAF}\right)$ were obtained from Bachem Feinchemikalien (Bubendorf, Switzerland). Poly-ethylene glycol MW 6000 and gelatin were purchased from BDH (Kilsyth, Victoria, Australia) and Bio-Rad (Richmond, CA, USA) respectively. Organic solvents were obtained from Ajax Chemicals (Sydney, Australia). Sheep anti-PAF antiserum, normal sheep serum and donkey anti-sheep immunoglobulin were generous gifts from Silenus Laboratories (Melbourne, Australia) (these are now available from New England Nuclear (Boston, MA, USA) as a PAF RIA kit product number NEK-062). [ ${ }^{125}$ I]PAF (sp. act. $2200 \mathrm{Ci} / \mathrm{mmol}$ ) was obtained from New England Nuclear. All other chemicals were purchased from the Sigma Chemical Co. (St Louis, MO, USA). Phosphate-buffered saline (PBS) was 0.05 m-potassium phosphate pH 7.4 with $0.9 \%(\mathrm{w} / \mathrm{v}) \mathrm{NaCl}$, and the RIA assay buffer was $0.05 \mathrm{M}$-sodium acetate $\mathrm{pH} 6.0$ containing $0.05 \%$ Tween 20 .

\section{Results}

\section{Measurement of PAF by RIA}

Under the assay conditions described, the binding of $\left[{ }^{125} \mathrm{I}\right] \mathrm{PAF}$ to anti-PAF antiserum at the concentrations used was $55-60 \%$, while non-specific binding was below $1.6 \%$. The standard inhibition curve was generally linear in the range 25 to 1000 pg PAF per tube, with $50 \%$ inhibition occurring with approximately $200 \mathrm{pg}$. The assay was sensitive down to $10 \mathrm{pg}$ PAF per tube.

Initial attempts to assay directly for PAF in embryo culture medium showed that the presence of BSA in the RIA buffer interfered with the performance of the assay. Samples of culture medium were therefore extracted with chloroform/methanol (Bligh \& Dyer, 1959), achieving recovery rates greater than $85 \%$.

Analysis of 24-h cultures of 2-cell embryos, compacted morulae or blastocysts, showed that PAF was not detected in the culture media from any of the embryo stages examined (Table 1). Likewise, immunoreactive PAF could not be detected in direct extracts from the embryos (Table 1). Calculations show that the total amount of PAF in each culture tube was below the sensitivity of the assay, being less than $26 \mathrm{pg}$ per $25-45$ embryos.

Table 1. PAF levels in mouse embryos and culture media, as determined by RIA

\begin{tabular}{lccc}
\hline $\begin{array}{l}\text { Development stage } \\
\text { of embryos* }\end{array}$ & $\begin{array}{c}\text { No. of } \\
\text { embryos }\end{array}$ & $\begin{array}{c}\text { Total } \\
\text { cell-associated } \\
\text { PAF (pg) }\end{array}$ & $\begin{array}{c}\text { Total PAF in } \\
\text { culture medium } \\
(\mathrm{pg})\end{array}$ \\
\hline Medium only & - & - & $<26$ \\
2-Cell & 30 & $<25$ & $<26$ \\
Compacted morula & 45 & $<25$ & $<26$ \\
Blastocyst & 25 & $<25$ & $<26$ \\
\hline
\end{tabular}

*Embryos were cultured in duplicate in $0.25 \mathrm{ml} \mathrm{M} 16$ culture medium, and each sample was assayed in duplicate.

\section{Platelet aggregation studies}

Samples of embryo culture medium were also tested for PAF biological activity using the washed rabbit-platelet aggregation bioassay. In each case, levels of PAF were below the detectable limit of $10 \mathrm{pg}$. To determine whether inhibitors of PAF activity were present in the samples which could inhibit the response of endogenous PAF, platelets were incubated with the extract before stimulation with synthetic PAF. In all cases, the response of platelets to added PAF was similar to that of controls which contained no embryo culture medium or embryo extracts. A typical result is shown in Fig. 1. This indicates that the inability to detect PAF biological activity in these embryo samples is not due to embryo factors which inhibit PAF activity. 


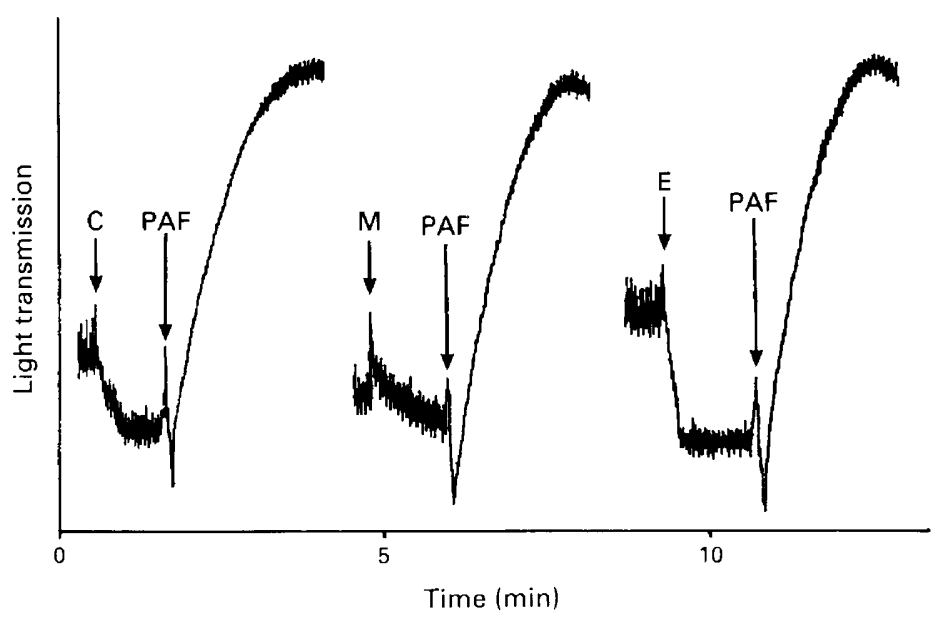

Fig. 1. Profiles for the aggregation of rabbit washed platelets stimulated with extracts $(5 \mu l)$ followed by PAF ( $50 \mathrm{pg}$ ). C, control (ethanol); M, 2-cell embryo culture medium (10 $\mu$ l) extract; E, extract of 2-cell embryos (equivalent to 1.25 embryos).

\section{Stability of PAF during embryo culture}

To determine whether embryos produce enzymes which may degrade PAF during the culture period, culture media with or without embryos were supplemented with known concentrations of $\mathrm{C}_{18}-\mathrm{PAF}$ at the start of embryo culture. The amount of PAF remaining after $24 \mathrm{~h}$ culture at $37^{\circ} \mathrm{C}$ was determined by RIA (Table 2). The amount of PAF recovered in embryo-free culture medium after $24 \mathrm{~h}$ was identical to that added ( $0 \mathrm{~h}$ culture). The presence of embryos in the culture medium resulted in no significant decrease in PAF activity at any concentration of PAF added (1.78, 7.12 and $17.8 \mathrm{ng} / \mathrm{ml}$ ).

Table 2. Stability of PAF during embryo culture

\begin{tabular}{lccc}
\hline & $\begin{array}{c}\text { Added } \mathrm{C}_{18} \text {-PAF } \\
(\mathrm{ng} / \mathrm{ml})^{*}\end{array}$ & $\begin{array}{c}\text { Incubation } \\
\text { time }(\mathrm{h})\end{array}$ & $\begin{array}{c}\text { Observed PAF } \\
(\mathrm{ng} / \mathrm{ml}) \dagger\end{array}$ \\
\hline Medium only & 1.78 & 0 & $2 \cdot 14 \pm 0.03$ \\
Medium only & 1.78 & 24 & $2.35 \pm 0.29$ \\
Blastocysts & 1.78 & 24 & $1.88 \pm 0.07$ \\
Medium only & 7.12 & 0 & $7.95 \pm 0.49$ \\
Medium only & 7.12 & 24 & $7.65 \pm 0.19$ \\
Blastocysts & 7.12 & 24 & $7.20 \pm 0.32$ \\
Medium only & 17.8 & 0 & $20.8 \pm 0.5$ \\
Medium only & 17.8 & 24 & $20.6 \pm 0.8$ \\
Blastocysts & 17.8 & 24 & $18.3 \pm 0.8$ \\
\hline
\end{tabular}

*Stock concentration was $35.6 \pm 1.6 \mu \mathrm{g} / \mathrm{ml}$, determined by RIA. $\dagger$ Values are the mean \pm s.e.m. of 4 determinations by RIA.

\section{Discussion}

The results presented in this study demonstrate that significant quantities of PAF are not produced by cultured mouse preimplantation embryos. Using a highly specific and sensitive RIA with a detection limit of 1 pg per embryo (Smal et al., 1990b), PAF was not observed in the embryo 
culture medium or in cell-associated material extracted from 2-cell embryos, compacted morulae, or blastocysts. The possibility that PAF was synthesized and secreted by preimplantation embryos, but was degraded during the culture period was tested by the ability to recover PAF which was added exogenously to the embryo cultures. No significant degradation of exogenous PAF was demonstrated by 2-cell embryos or blastocysts over a 24 -h period of incubation. The possibility of intracellular metabolism of endogenous PAF could not be excluded by these experiments.

The PAF RIA described here and elsewhere (Smal et al., 1990b) is based on an antiserum raised to a chemically defined PAF antigen (Smal et al., 1989). Recent combining-site studies have shown that the antiserum is highly specific for PAF (Smal et al., 1990a). The immunoreactivities of PAF analogues that are likely to occur naturally are summarized in Table 3 . In brief, the antiserum is specific for (1) an ether-linked alkyl chain at carbon 1 of the glyceryl backbone of PAF, (2) a shortchain acyl group ( 2 or 3 carbons) at carbon 2, and (3) to a lesser extent for a phosphorylcholine group at carbon 3. Thus the PAF radioimmunoassay will detect, in addition to PAF itself, only the various 1-0-alkyl homologues of PAF, the 2-0-propionyl analogue, and the various $\mathrm{N}$ demethylated analogues. All of these analogues have some degree of biological activity (Braquet $\&$ Godfroid, 1987) and should therefore be detected in any measurement of 'PAF'. The analogues of PAF which are not detected by the assay are the 1-0-acyl and 2-0-long-chain acyl analogues. While these are likely to occur naturally, they have little or no biological activity (Braquet \& Godfroid, 1987). The commonly occurring lipids show no cross-reactivity at concentrations up to $20 \mu \mathrm{g} / \mathrm{ml}$ (Smal et al., 1990a,b). We conclude, therefore, that mouse embryos do not synthesize either PAF itself, or any of the PAF analogues that have biological activity similar to PAF.

Table 3. Cross-reactivity of PAF analogues in the PAF RIA

\begin{tabular}{|c|c|c|c|}
\hline Compound & Substituent* & Position & $\mathrm{IC}_{50} / \mathrm{IC}_{50} \mathrm{C}_{16}-\mathrm{PAF}$ \\
\hline $\mathrm{C}_{16}-\mathrm{PAF}$ & $-\mathrm{O}-\left(\mathrm{CH}_{2}\right)_{15} \mathrm{CH}_{3}$ & $\mathrm{C} 1$ & 1.0 \\
\hline $\mathrm{C}_{18} \cdot \mathrm{PAF}$ & $-\mathrm{O}-\left(\mathrm{CH}_{2}\right)_{17} \mathrm{CH}_{3}$ & $\mathrm{Cl}$ & 1.85 \\
\hline $\mathrm{C}_{18: 1}-\mathrm{PAF}$ & $-\mathrm{O}-\left(\mathrm{CH}_{2}\right)_{8} \mathrm{CH}=\mathrm{CH}\left(\mathrm{CH}_{2}\right)_{7} \mathrm{CH}_{3}$ & $\mathrm{Cl}$ & $1 \cdot 23$ \\
\hline Palmitoyl-AGPC & $-\mathrm{O}-\mathrm{C}-\left(\mathrm{CH}_{2}\right)_{16} \mathrm{CH}_{3}$ & $\mathrm{Cl}$ & $>256$ \\
\hline Lyso- $\mathrm{C}_{16}-\mathrm{PAF}$ & ${ }_{\mathrm{O}}^{\mathrm{OH}}$ & $\mathrm{C} 2$ & 40000 \\
\hline PGEPC & $\begin{array}{c}-\mathrm{O}-\mathrm{C}-\mathrm{C}-\mathrm{CH}_{2} \mathrm{CH}_{3} \\
\mathrm{O}\end{array}$ & $\mathrm{C} 2$ & $4 \cdot 4$ \\
\hline BuGEPC & $\begin{array}{c}-\mathrm{O}-\mathrm{C}-\left(\mathrm{CH}_{2}\right)_{2} \mathrm{CH}_{3} \\
\mathrm{O}\end{array}$ & $\mathrm{C} 2$ & $>256$ \\
\hline HGEPC & $-\mathrm{O}-\mathrm{C}-\left(\mathrm{CH}_{2}\right)_{4} \mathrm{CH}_{3}$ & $\mathrm{C} 2$ & $>256$ \\
\hline AGEPDME & $\begin{array}{c}\mathrm{O}-\mathrm{P}-\mathrm{O}-\left(\mathrm{CH}_{2}\right)_{2} \mathrm{~N}^{+} \mathrm{H}\left(\mathrm{CH}_{3}\right)_{2} \\
\mathrm{O}^{-} \\
\mathrm{O}\end{array}$ & $\mathrm{C} 3$ & $5 \cdot 9$ \\
\hline AGEPE & $-\mathrm{O}-\underset{\mathrm{O}}{\mathrm{P}}-\mathrm{O}-\left(\mathrm{CH}_{2}\right)_{2} \mathrm{NH}_{3}{ }^{+}$ & $\mathrm{C} 3$ & 53.8 \\
\hline
\end{tabular}

*Replacement of the substituent groups in the structure of PAF (1-0-alkyl-2-0-acetyl-sn-glycero-3phosphocholine).

†Carbons 1, 2 and 3 of the glyceryl backbone of PAF. 
In addition to negative results in the RIA, we were unable to detect PAF activity in embryo culture media by the washed rabbit-platelet bioassay. Endogenous inhibitors of PAF activity in crude cell extracts which can mask the presence of endogenous PAF have been reported (Miwa et al., 1987). However, embryo extracts used in our study were found to contain no factors which inhibited platelet aggregation in the bioassay.

Our results show that the amount of PAF produced by mouse embryos after 24-h culture is less than $1 \mathrm{pg} / \mathrm{embryo}$, using either the RIA or the bioassay. Very low levels of mouse-embryo PAF ( $\leqslant 40 \mathrm{pg} / \mathrm{embryo}$ ) have been detected using the platelet serotonin-release bioassay (Angle et al., 1988a). Maximal production of PAF appeared to coincide with the morula stage of development, and was influenced by the concentration and source of human serum in the culture medium. The embryo culture methods used in these studies differ from those used by Angle et al. (1988b) but nevertheless routinely produce blastocysts which have $80-90 \%$ implantation rates after transfer to pseudopregnant foster mice (unpublished observations). The values in the present study differ significantly from the previously published levels of $800-16700 \mathrm{pg} \mathrm{PAF} / \mathrm{embryo} / 24 \mathrm{~h}$, when measured by a rabbit whole-blood bioassay (Collier et al., 1988). The splenectomized mouse bioassay has also been used to quantitate embryo-derived PAF, with similar results (O'Neill et al., 1987). The specificity of these bioassays for PAF detection needs to be questioned, since stimulation of the many cellular components present in these assays may lead to activation of platelets. Indeed, mouse platelets appear to be unresponsive to synthetic PAF (Lanara et al, 1982), suggesting that the decreased platelet count in the splenectomized mouse bioassay might be mediated by factors other than PAF. Culture media of human embryos have been tested by both the splenectomized mouse bioassay and, concurrently, rabbit washed-platelet aggregation assay. PAF-activity was detected by the former but not by the latter assay (Amiel et al., 1989). However, there may be species differences in the production of PAF by preimplantation embryos, and the specific RIA used in this study will be useful for such an analysis.

Although our studies indicate that viable mouse embryos do not produce significant quantities of PAF or one of the biologically active analogues of PAF, the disparity between our results and those previously published may be due to a different molecular nature of embryo-derived PAF. Since no mass spectral data are available for embryo-derived PAF, the exact chemical structure is not known. While the chromatographic and pharmacological behaviour of embryo-derived PAF indicate a PAF-like molecule (Collier et al., 1988), it remains possible that even a small variation from the established structure of PAF (Hanahan et al., 1980) may be sufficient to eliminate immunoreactivity in the RIA, and abolish biological activity as measured by the rabbit washedplatelet bioassay. Further chemical analyses are required before it can be established whether preimplantation embryos produce molecules which are structurally similar to PAF and can hence be called PAF-like, or structurally distinct molecules which nevertheless elicit responses similar to PAF in certain biological assays.

This work was supported by the National Health and Medical Research Council of Australia and the Infertility Medical Centre, Melbourne.

\section{References}

Acker, G., Hecquet, F., Etienne, A., Braquet, P. \& Mencia-Huerta, J.M. (1988) Role of plateletactivating factor (PAF) in the ovoimplantation in the rat: effect of the specific PAF-acether antagonist, BN 52021. Prostaglandins 35, 233-240.

Acker, G., Braquet, P. \& Mencia-Huerta, J.M. (1989) Role of platelet-activating factor (PAF) in the initiation of the decidual reaction in the rat. J. Reprod. Fert. 85, 623-629.

Amiel, M.L., Duquenne, C., Benveniste, J. \& Testart, J.
(1989) Platelet aggregating activity in human embryo culture media free of PAF-acether. Hum. Reprod. 4, $327-330$.

Angle, M.J., Byrd, W. \& Johnson, J.M. (1988a) Embryonic production of platelet-activating factor. Fert. Steril., Suppl. 596, Abstr. P-158.

Angle, M.J., Jones, M.A., McManus, L.M., Pinckard, R.N. \& Harper, M.J.K. (1988b) Platelet-activating factor in the rabbit uterus during early pregnancy. $J$. Reprod. Fert. 83, 711-722. 
Bligh, E.G. \& Dyer, W.J. (1959) A rapid method of total lipid extraction and purification. Can. J. Biochem. Physiol. 37, 91 1-917.

Braquet, P. \& Godfroid, J.J. (1987) Conformational properties of the PAF-acether receptor on platelets based on structure-activity studies. In PlateletActivating Factor and Related Lipid Mediators, pp. 19l-238. Ed. F. Snyder. Plenum Press, New York.

Collier, M., O'Neill, C., Ammit, A.J. \& Saunders, D.M. (1988) Biochemical and pharmacological characterization of human embryo-derived platelet activating factor. Hum. Reprod. 3, 993-998.

Farr, R.S., Cox, C.P., Wardlow, M.L. \& Jorgensen, R. (1980) Preliminary studies of an acid labile factor (ALF) in human sera that inactivates platelet activating factor (PAF). Immunol. Immunopathol. 15, $318-330$.

Hanahan, D.J. \& Weintraub, S.T. (1985) Plateletactivating factor; isolation, identification and assay. Methods Biochem. Analysis 31, 195-219.

Hanahan, D.J., Demopoulos, C.A., Liehr, J. \& Pinckard, R.N. (1980) Identification of platelet activating factor as acetyl glyceryl ether phosphorylcholine. J. biol. Chem. 255, 5514-5516.

Lanara, E., Vakirtzi-Lemonias, C., Kritikou, L. \& Demopoulos, C.A. (1982) Response of mice and mouse platelets to acetyl glyceryl ether phosphoryIcholine. Biochem. Biophys. Res. Commun. 109, 1148-1156.

Milligan, S.R. \& Finn, C.A. (1990) Failure of plateletactivating factor (PAF-acether) to induce decidualization in mice and failure of antagonists of PAF to inhibit implantation. J. Reprod. Fert. 88, 105-112.

Miwa, M., Hill, C., Kumar, R., Sugatani, J., Olson, M.S. \& Hanahan, D.J. (1987) Occurrence of an endogenous inhibitor of platelet-activating factor in rat liver. J. biol. Chem. 262, 527-530.

O'Neill, C., Gidley-Baird, A.A., Pike, I.L. \& Saunders, D.M. (1987) Use of a bioassay for embryo-derived platelet activating factor as a means of assessing quality and pregnancy potential of human embryos. Fert. Steril. 47, 969-975.

O'Neill, C., Collier, M., Ammit, A.J., Ryan, J.P., Saunders, D.M. \& Pike, I.L. (1989) Supplementation of in-vitro fertilisation culture medium with platelet activating factor. Lancet ii, 769-772.

Pinckard, R.N., Farr, R.S. \& Hanahan, D.J. (1979) Physicochemical and functional identity of rabbit platelet-activating factor (PAF) released in vivo during $1 \mathrm{gE}$ anaphylaxis with PAF released in vitro from $\mathrm{IgE}$ sensitized basophils. J. Immunol. 123, 1847-1857.

Quinn, P., Barros, C. \& Whittingham, D.G. (1982) Preservation of hamster ooytes to assay the fertilizing capacity of human spermatozoa. $J$. Reprod. Fert. 66, $16 \mathrm{l}-168$.

Ryan, J.P., Spinks, N.R. \& O'Neill, C. (1989) Platelet activating factor (PAF) production by mouse embryos in vitro and its effects on embryonic metabolism. J. cell. Biochem. 40, 387-395.

Smal, M.A., Baldo, B.A. \& Redmond, J.W. (1989) Production of antibodies to platelet activating factor. Molec. Immunol. 26, 711-719.

Snal, M.A., Baldo, B.A. \& Harle, D.G. (1990a) The specificity of the binding of platelet-activating factor (PAF) to anti-PAF antibodies. J. molec. Recognition (in press).

Smal, M.A., Baldo, B.A. \& McCaskill, A. (1990b) A specific and sensitive radioimmunoassay for platelet activating factor. J. Immunol. Methods 128, 183-188.

Spinks, N.R. \& O'Neill, C. (1988) Antagonists of embryoderived platelet-activating factor prevent implantation of mouse embryos. J. Reprod. Fert. 84, 89-98.

Spinks, N.R., Ryan, J.P. \& O'Neill, C. (1990) Antagonists of embryo-derived platelet-activating factor act by inhibiting the ability of the mouse embryo to implant. J. Reprod. Fert. 88, 241-248.

Whittingham, D.G. (197I) Culture of mouse ova. $J$. Reprod. Fert., Suppl. 14, 7-21.

Received 16 January 1990 